Reprod. Nutr. Dévelop., 1980, 20 (3 A), 647-651.

\title{
Plasma calcium, inorganic phosphorus and magnesium levels in pregnant and lactating rabbits
}

\author{
par J.-P. BARLET
}

Laboratoire des Maladies Métaboliques, I. N. R. A.,

Theix, Saint-Genès-Champanelle, 63110 Beaumont.

Summary. Plasma calcium and inorganic phosphorus concentrations were significantly lower in 14 female rabbits during the last 20 days of pregnancy and the first 20 days of lactation than in 11 non-pregnant, non-lactating controls. Plasma magnesium level was similar in both groups. Plasma calcium and inorganic phosphorus levels were very low $(5.8 \pm 0.4$ and $2.9 \pm 0.3 \mathrm{mg} / \mathrm{dl}$, respectively) in 6 lactating rabbits afflicted with tetany between 7 and 18 days postpartum. When they were intraperitoneally injected with calcium, the calcium and phosphate levels returned to normal within $2 \mathrm{~h}$.

\section{Introduction.}

There are few data on the regulation of plasma calcium and phosphate concentrations in rabbits (Mclsaac, 1927 ; Economou-Mavrou and McCance, 1958). Graham and Porter (1971) measured maternal and fotal calcaemia during the latter half of pregnancy in New Zealand White rabbits and found that between days 16 and 21 of pregnancy, fotal plasma calcium fell from the maternal level of $12.5 \mathrm{mg} / \mathrm{dl}$ or above to $1.6 \mathrm{mg} / \mathrm{dl}$ below that level. Fœetal calcaemia then rose to about $12.5 \mathrm{mg} / \mathrm{dl}$ at 30 days of pregnancy, while maternal calcaemia simultaneously dropped to $11 \mathrm{mg} / \mathrm{dl}$.

We observed previously (Barlet, unpublished data) that during the first month of lactation, some rabbits present a syndrome, similar to parturient paresis in dairy cows (Marr, Moodie and Robertson, 1955 ; Barlet, 1969), which is characterized by tetany and lowered plasma calcium levels. In the present work, we measured plasma calcium, inorganic phosphorus and magnesium concentrations in rabbits during the last days of pregnancy and the first month of lactation.

\section{Material and methods.}

Thirty-one 8-month old female Fauve de Bourgogne rabbits, weighing 2.9 to $3.3 \mathrm{~kg}$ at the beginning of the experiment, were used. They were housed on straw in individual cages and fed a commercial chow (UCAAB), luzern hay and water ad libitum. Fourteen were mated with a male of the same breed, and used from day 11 after mating until day 20 postpartum. The length of pregnancy in the Fauve de Bourgogne breed is $31 \pm 0.5$ days. After parturition, the litters remained with the mothers ; 
they were weaned at 60 days. Eleven non-pregnant, non-lactating females of the same age and weight were used as controls.

Six lactating females of the colony developed tetany between days 7 and 18 postpartum. As soon as the first symptoms appeared, the animals were treated by intraperitoneal injection of calcium gluconate $(0.6 \mathrm{~g}$ calcium $/ \mathrm{kg}$ body weight).

Serial blood samples $(1 \mathrm{ml})$ were obtained from each animal by puncture of an external ear vein. After centrifugation the plasma was frozen until analysis. Plasma calcium and magnesium were measured by atomic absorption spectrophotometry (Perkin Elmer 400). Plasma inorganic phosphorus was determined by colorimetry (Kalckar, 1947).

\section{Results.}

The plasma calcium concentration of the 14 pregnant rabbits decreased from $13.5 \pm 0.2 \mathrm{mg} / \mathrm{dl}$ on day 11 postcoitum to $10.5 \pm 0.5 \mathrm{mg} / \mathrm{dl}(\mathrm{P}<0.01)$ at $24 \mathrm{~h}$ postpartum. During the same period, plasma inorganic phosphorus concentration decreased from $6.0 \pm 0.4 \mathrm{mg} / \mathrm{dl}$ to $3.8 \pm 0.3 \mathrm{mg} / \mathrm{dl}(P<0.05)$, while plasma magnesium did not change significantly (mean value : $2.01 \pm 0.03 \mathrm{mg} / \mathrm{dl}$ ).

The plasma calcium (mean value : $9.8 \pm 0.3 \mathrm{mg} / \mathrm{dl}$ ), inorganic phosphorus $(3.7 \pm 0.5 \mathrm{mg} / \mathrm{dl})$ and magnesium $(1.98 \pm 0.02 \mathrm{mg} / \mathrm{dl})$ levels of these pregnant rabbits remained unchanged during the first 20 days postpartum, but were always lower than in the non-lactating, non-pregnant controls (calcium : $13.8 \pm 0.2 \mathrm{mg} / \mathrm{dl}$, $P<0.01$; inorganic phosphorus : $6.1 \pm 0.4 \mathrm{mg} / \mathrm{dl}, \mathrm{P}<0.01$; magnesium : $2.03 \pm 0.02$, $P<0.05)$. These differences disappeared on day 70 postpartum (10 days after weaning) (fig. 1).

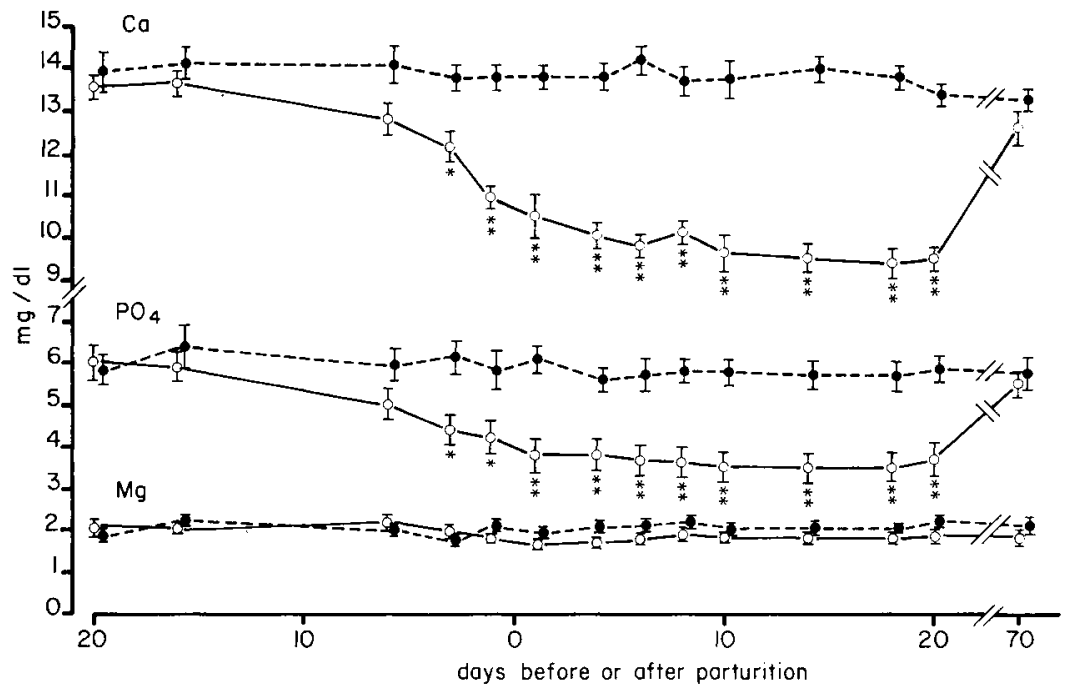

FIG. 1. - Plasma calcium (Ca), inorganic phosphorus $\left(\mathrm{PO}_{4}\right)$ and magnesium $(\mathrm{Mg})$ concentrations in 14 rabbits (solid lines) during the last 20 days of pregnancy and the first 20 days of lactation and in 11 controls (dotted lines) (mean $\pm \mathrm{SEM})(* \mathrm{P}<0.05 ; * * \mathrm{P}<0.01)$. Student's t-test was used to compare the two groups. 
A tetany crisis developed in 6 lactating rabbits between days 7 and 18 postpartum. No particular symptom, except loss of appetite, was observed the day before the crisis. On the morning of the crisis, all animals were found lying on the side; they presented such symptoms as ear flapping, jerking of the posterior limbs and muscle tremors. Plasma calcium $(5.8 \pm 0.4 \mathrm{mg} / \mathrm{dl})$ and inorganic phosphorus $(2.9 \pm 0.3 \mathrm{mg} / \mathrm{dl})$ concentrations were very low, while magnesaemia $(1.96 \pm 0.04 \mathrm{mg} / \mathrm{dl})$ was similar to that measured in normal lactating rabbits. Intraperitoneal calcium gluconate injection induced a rapid recovery within $2 \mathrm{~h}$, and plasma calcium and phosphate levels returned to normal (fig. 2). No relapse was observed, and none of the 54 young rabbits of the 6 litters died.

FIG. 2. - Plasma calcium ( $\mathrm{Ca}$; dotted line) and inorganic phosphorus $\left(\mathrm{PO}_{4}\right.$; solid line) concentrations in 6 hypocalcaemic lactating rabbits after an intraperitoneal calcium injection of $0.6 \mathrm{mg} \mathrm{Co} / \mathrm{kg}$ body weight (arrow) (mean \pm SEM).

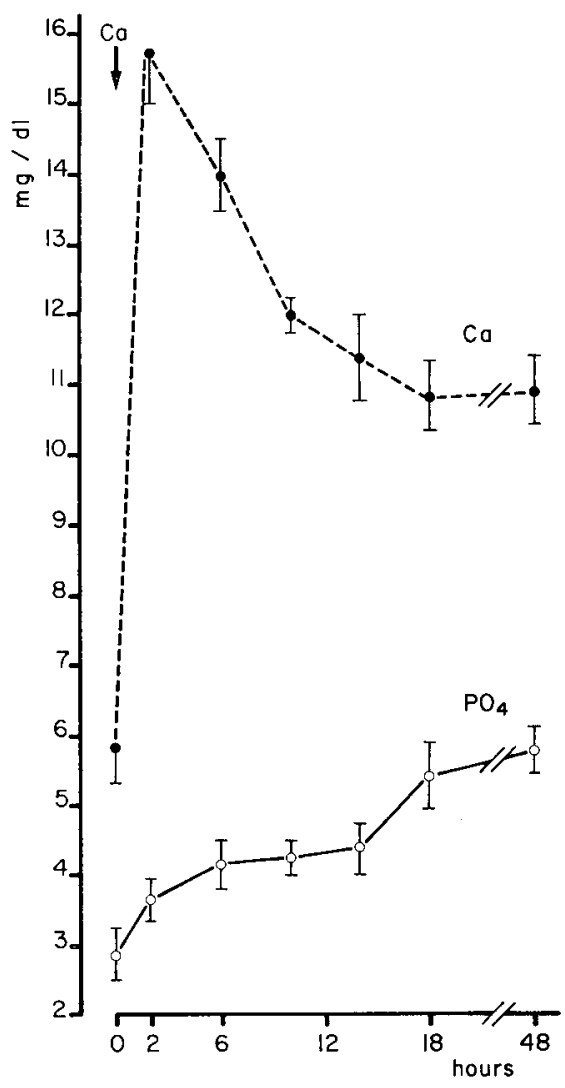

\section{Discussion.}

Plasma calcium concentrations (mean value : $12.37 \pm 0.38 \mathrm{mg} / \mathrm{dl}$ for 350 measurements) were higher than those reported in most mammals whose calcaemia is about $10 \mathrm{mg} / \mathrm{dl}$. However, in male Chinchilla rabbits, plasma calcium concentrations were higher than $13.5 \mathrm{mg} / \mathrm{dl}$ (Agkün and Rudman, 1969). Rabbits fed large amounts of calcium do not reduce intestinal calcium absorption, and simultaneously increase its endogenous excretion in urine and faeces (Besançon and Lebas, 1969). However, 
this increased excrefion dos not seem sufficient to regulate efficiently plasma calcium concentration. Thus in contrast to most mammals, rabbit blood seems to reflect the dietary calcium level, as plasma calcium increases concomitantly with dietary calcium (Chapin and Smith, 1967).

As far as we know, this is the first time that plasma calcium, phosphate and magnesium concentrations have been extensively measured during pregnancy and lactation in rabbits. Very little is known about the regulation of magnesaemia in these females. In near-term pregnant rabbits, ${ }^{28} \mathrm{Mg}$ crosses from the maternal placenta to the fotus, and in spite of the lower concentration of fotal tissues, ${ }^{28} \mathrm{Mg}$ uptake is rapid and increases until delivery (Aïkawa and Bruns, 1960). In our experimental conditions, no significant variations were observed in maternal plasma magnesium concentrations (fig. 1), even in hypocalcaemic animals.

The mean milk production of Fauve de Bourgogne rabbits during the first 6 weeks postpartum is $7.09 \pm 0.28 \mathrm{~kg}$, the lactation curve showing a maximum at about day 19 (Lebas, 1968). Similar results have been reported in New Zealand White and Dutch rabbits (Cowie, 1969). Rabbit's milk is rich in calcium (about $5 \mathrm{~g} / \mathrm{l}$ ) (Guéguen, 1971) and phosphate (4-5 g/l) (Anderson ef al., 1975). Thus, the drain of calcium and phosphate through the mammary gland creates an imperative need for them. Marked hypocalcaemia (fig. 2) with tetany was observed in some lactating rabbits. However, 10 days after weaning, plasma calcium and phosphate concentrations were similar in lactating and non-lactating females (fig. 1). Calcium injection induced a rapid recovery in hypocalcaemic rabbits (fig. 2 ).

In conclusion, our results demonstrate that the end of pregnancy and the beginning of lactation in rabbits is associated with a mild hypocalcaemia and hypophosphataemia. In some animals, this drop is more pronounced and associated with tetany which can be easily cured by calcium injection.

Reçu en juillet 1979.

Accepté en octobre 1979.

Résumé. Chez 14 lapines Fauve de Bourgogne, durant les 20 derniers jours de gestation et les 20 premiers jours de lactation, la calcémie et la phosphatémie étaient significativement inférieures à celles de 11 témoins ni gestantes, ni allaitantes. Ces différences disparaissaient $10 \mathrm{j}$ après le sevrage. La magnésémie des deux groupes d'animaux n'était jamais significativement différente.

Six lapines allaitantes furent atteintes de tétanie (animaux allongés sur le côté, présentant une agitation désordonnée des pattes postérieures et des tremblements musculaires) entre le $7 \mathrm{e}$ et $18^{\mathrm{e}} \mathrm{j}$ post partum. La calcémie $(5,8 \pm 0,4 \mathrm{mg} / \mathrm{dl})$ et la phosphatémie $(2,9 \pm 0,3$ $\mathrm{mg} / \mathrm{dl})$ de ces animaux étaient alors très abaissées, mais leur magnésémie $(1,96 \pm 0,04 \mathrm{mg} /$ dl) étaił normale. Une injection calcique intrapéritonéale $(0,6 \mathrm{~g}$ de calcium $/ \mathrm{kg}$ de poids vif) amenait un rétablissement rapide des animaux, associé à un retour à la normale de leur calcémie et de leur phosphatémie.

\section{References}

AGKÜN S., RUDMAN D., 1969. Relationships between mobilization of free fatty acids from adipose tissue, and the concentrations of calcium in the extracellular fluid and in the tissue. Endocrinology, 84, 926-930.

AIIKAWA J. K., BRUNS P. D., 1966. Placental transfer and felal tissue uptake of $\mathrm{Mg}^{28}$ in the rabbit. Proc. Soc. exp. Biol. Med., 105, 95-98. 
ANDERSON R. R., SADLER K. C., KNAUER M. W., WIPPLER J. P., MARSHALL R. T., 1975. Composition of cottontail rabbit milk from stomach of young and directly from gland. J. Dairy Sci., 58, 1449-1452.

BARLET J. P., 1969. Variations de la calcémie et de la phosphatémie chez la vache laitière au moment du vêlage : rôle probable de la calcitonine dans l'ériologie du syndrome. Rech. vétér., 2, 93-100.

BESANÇON P., LEBAS F., 1969. Utilisation digestive réelle et rétention du calcium par le lapin en croissance recevant un régime riche en calcium et en phosphore. Ann. Zootech., 18, 437-443.

CHAPIN R. E., SMITH S. E., 1967. The calcium tolerance of growing and reproducing rabbits. Cornell Vet., 57, 480-491.

COWIE A. T., 1969. Variations in the yield and the composition of the milk during lactation in the rabbit and the galactopoietic effect of prolactin. J. Endocrinol., 44, 437-450.

ECONOMOU-MAVROU C., MCCANCE R. A., 1958. Calcium, magnesium and phosphorus in fatal tissues. Biochem. J., 68, 573-580.

GRAHAM R. W., PORTER G. P., 1971. Fetal-maternal plasma calcium relationships in the rabbit. Quartely J. exp. Physiol., 56, 160-168.

GUÉGUEN L., 1971. La composition minérale du lait et son adaptation aux besoins minéraux du jeune. Ann. Nutr. Alim., 25, A335-A381.

KALCKAR H. M., 1947. The enzymatic synthesis of purine ribosides. J. biol. Chem., 167, 477-486. LEBAS F., 1968. Mesure quantitative de la production laitière chez la lapine. Ann. Zaotech., 17, 169182.

MARR A., MOODIE E. W., ROBERTSON A., 1955. Some biochemical and clinical aspects of milkfever. J. comp. Path., 65, 347-365.

McISAAC P., 1927. Studies on calcium metabolism. III. Comparison in calcium metabolism of doe and litter in the rabbit. J. exp. Biol., 5, 248-251. 